\title{
Natural auxiliary coagulants - perspectives for the treatment of textile wastewater
}

\author{
Chất trọ keo tụ tụ nhiên - tiềm năng úng dụng trong xử lý nước thải dệt nhuộm \\ Research paper
}

Dao Minh Trung ${ }^{1 *}$; Tran Thi Thanh Ngoc ${ }^{2}$; Nguyen Thi Thao Tran ${ }^{3}$; Ngo Kim Dinh ${ }^{4}$; Nguyen Vo Chau Ngan ${ }^{5}$

${ }^{I}$ Thu Dau Mot University; ${ }^{2}$ Industrial University of Ho Chi Minh City; ${ }^{3}$ University of Science - Vietnam National University of Ho Chi Minh City; ${ }^{4}$ Ministry of Transport; ${ }^{5}$ Can Tho University, Vietnam

\begin{abstract}
Applying chemical coagulants and auxiliary coagulants in wastewater treatment has become more popular in Vietnam. Although the efficacy of chemical coagulants has been well recognized, there are disadvantages associated with the use of these products, such as the inefficiency at low temperatures, increasing the residual cation in solution, causing health problems and distribution water, relatively high cost, producing high volume of sludge. Thus, it is desirable to replace these chemical coagulants for products that do not generate such drawbacks, such as natural polymers. In this paper, the authors conducted experiments by using natural auxiliary coagulants extracted from seeds of Cassia fistula (gum MHY) and chemical polymer as auxiliary coagulation to treat textile wastewater with basic polluted parameters: $\mathrm{pH}=9.0 ; \mathrm{COD}=800 \mathrm{mgO}_{2} / \mathrm{L}$, color $=750 \mathrm{Pt}-\mathrm{Co}$. The Jartest experiment results showed that the process efficiency of chemical polymer and gum MHY is not so different, with the COD removal efficiencies of $60.3 \%$ and $59.7 \%$; the color removal efficiencies of $87.3 \%$ and $87.1 \%$; the SS removal efficiencies of $93.2 \%$ and $92.6 \%$. There-fore, coagulants obtained from gum MHY can be applied as the alternatives for chemical polymer in the process of treating textile wastewater.
\end{abstract}

Các ứng dụng chất keo tu và chất trọ keo tu hóa học trong xủ lý nuớc thải ngày càng trở nên phổ biến tại Việt Nam. Mặc dù có nhiều ghi nhận về hiệu quả xử lý của chất keo tu hóa học, phuoong pháp xủ lý này vẫn tồn tại một số nhuợc điểm nhu hiệu suất xử lý thấp ở nhiệt độ thấp, nuớc thải sau khi xử lý còn chứa nhiều hóa chất tiếp tuc làm ô nhiễm nguồn tiếp nhận, chi phí xủ lý cao và tạo ra nhiều bùn thải. Do đó việc tìm kiếm một phưong án xử lý thay thế, chẳng hạn sử dụng polymer tụ nhiên, có thể khắc phuc những nhuợc điểm này là rất cần thiết. Nghiên cứu này tiến hành đánh giá hiệu quả sử dụng chất trợ keo tụ sinh học ly trích tù hạt trái Muồng Hoàng yến (Cassia fistula) và chất trợ keo tu hóa học để xử lý nuớc thải dệt nhuộm có các thông số ô nhiếm co bản: $p H=9,0$; $C O D=800 \mathrm{mgO}_{2} / \mathrm{L}$, độ màu $=750$ Pt-Co. Các thí nghiệm trên bộ Jartest cho thấy hiệu quả xử lý nuớc thải dệt nhuộm của chất trợ keo tu gum Muồng Hoàng yến và chất trợ keo tu hóa học không khác biệt có ý nghĩa với hiệu suất xử lý COD lần luợt là 60,3 và 59,7\%; hiệu suất xử lý độ màu là 87,3 và 87,1\%; xủ lý SS là 93,2 và 92,6\%. Kết quả nghiên cứu cho thấy gum hạt Muồng Hoàng yến có thể sủ dụng làm chất trọ̣ keo tụ thay thế chất trọ keo tụ hóa học trong xủ lý ô nhiểm nước thải dệt nhuộm.

Keywords: biological coagulant, cassia fistula seed, chemical coagulant, textile wastewater

\section{Introduction}

Nowadays, the textile industry of Vietnam has been extensively developed, providing diversified and multi-colorful products with high quality for increasing needs of consumers. This industry also attracts huge amount employments and promotes an increment in export volume of the country. However, textile is one of the fields that need massive use of water as well as chemicals and result in a variety of complex wastewater. The composition of wastewater from textile varies with different factors including the production factory, the type of cloth and dyeing environment (acidic, basic or neutral). Usually, in the dyeing process, absorption efficiency of dye ranges from 60 to $70 \%$ and the 
excess dye is in the original state or other decomposed ones. In addition, several electrolytes, surfactants, environment-making substances, etc. are also present in the wastewater (Le Xuan Hong, 2006). As a result, the textile wastewater often appears in deep color. Therefore, it is necessary and essential to solve the pollution of textile wastewater (Pham Ngoc Ho, 2009).

Different methods have been used to pre-treat the wastewater of textile industry. Among them, phytochemical method, using the chemically originated substances to treat the pollution is considered as one of the most popular methods. However, the excess of these substances after the treatment may, in its turn, contaminate again the treated water. Consequently, the study to find the alternative compounds is also crucial.

There is such of potential coagulants in Vietnam, in which Cassia fistula seed has been proved on high ability in industrial wastewater treatment. Moreover, these seeds would be safer for the environment in comparison to the chemical sources.

The study "Natural auxiliary coagulants - perspectives for the treatment of textile wastewater" is topical and relevant in this circumstance. Results from the study showed that it is able to utilize biological auxiliary coagulants to sub-stitute the chemical ones in the treatment of textile waste-water to improve the quality of water environment.

\section{Methodology}

\subsection{Materials}

Collect wastewater for study:

- Wastewater from factory 1 was taken at the discharge point of Phong Phu Textile Factory, Tang Nhon Phu ward, District 9, Ho Chi Minh city.

- Wastewater from factory 2 was taken at TK VINA Ltd Company, Bac Tan Uyen ward, Binh Duong province.

Chemicals: using the chemical coagulants and auxiliary coagulants including:

- PAC: $\mathrm{Al}_{\mathrm{n}}(\mathrm{OH})_{\mathrm{m}} \mathrm{Cl}_{\mathrm{n}-\mathrm{m}}$ and polymer $\left(-\mathrm{CH}_{2} \mathrm{CHCONH}_{2}-\right)_{\mathrm{n}}$ which are industrial grade.

- Gum extracted from Cassia fistula seeds collected in Binh Duong province. The gum is in solid state with the extraction efficiency is $150 \mathrm{~g}$ gum $/ 1.4 \mathrm{~kg}$ seed. The extraction was done following reported pro-cedure in previous studies by Pal \& Singh (2014) and Bhatnagar et al. (2013).

Instruments: the experiments were carried out on the labscale Jartest apparatus. The Jartest consist of 6 paddles simultaneously rotating at the same speed. The speed was adjustable through the gear. The time was controlled to find the best operating parameters.

\subsection{Experimental setup}

\subsubsection{Selecting the parameters for coagulation}

Nguyen Thi Lan Phuong (2008) recorded that, in a standard Jartest experiment, the stirring time of $2-3$ mins is considered as quick (stirring speed is in the range of 100 $200 \mathrm{rpm}$ ) while 20 - 30 mins is considered as slow stirring time (stirring speed ranges from 20 - $50 \mathrm{rpm}$ ). In addition, sedimentation time usually varies from 30 - 60 mins.

All following experiments were performed on Jartest in which samples were put in 6 beakers with the volume of 1 L. Each beaker contained around $500 \mathrm{~mL}$ of wastewater. The quick stirring speed was fixed at $120 \mathrm{rpm}$ in 2 mins meanwhile the slow one was $40 \mathrm{rpm}$ keeping for $25 \mathrm{mins}$. The sedimentation time was 30 mins.

According to Huynh Long Toan (2014), the used amount of coagulants may vary from $200-1000 \mathrm{mg} / \mathrm{L}$ for wastewater and $20-100 \mathrm{mg} / \mathrm{L}$ for drinking water. In this study, $150-300 \mathrm{mg} / \mathrm{L}$ was chosen for the experiments to find the best amount of PAC which plays the role of the coagulant (the step between samples is $r=50 \mathrm{mg} / \mathrm{L}$ ). In addition, the necessary concentration of the auxiliary coagulant usually falls in the range of $1.0-5.0 \mathrm{mg} / \mathrm{L}$ (Tran Hieu Nhue, 2001). Then, the auxiliary coagulant concentration of 5.0 $\mathrm{mg} / \mathrm{L}$ was used for the study.

\subsubsection{Methods}

\section{Sample collection and data analysis}

Sample collection: the wastewater for all experiments were collected 10 times ( 5 times for each factory). The uniform timepoint of collection is at $10 \mathrm{am}$.

Sample analysis: all samples were analysis according to the procedure regulated by current Vietnamese standards.

Data analysis: raw data were analyzed using MS Excel and statistics were done with SPSS.

\section{Experiments}

Experiment 1: determining the optimum amount of PAC

- Purpose: to find the optimum PAC quantity for the coagulation of the samples. The obtained result of this experiment would be used for the succeeding ones.

- Experimental procedure is as follows:

○ Step 1: 6 beakers were put on the Jartest apparatus, each beaker contained $500 \mathrm{~mL}$ of wastewater.

- Step 2: quickly stirred the wastewater in 2 mins with the stirring speed of $120 \mathrm{rpm}$. Depending on the experiment, various chemicals with suitable amount were added into the beakers. Then, slowly stirred with a speed of $40 \mathrm{rpm}$ for 25 mins. The solutions then were settled naturally in 30 mins. 
- Step 3: observed the sedimentation of the sludge, the clear water was decanted for $\mathrm{pH}$ and color intensity measurements as well as the analysis of the SS and COD measures.

Each experiment was repeated for 5 times. After data analysis, suitable amount of PAC was obtained as X (mg/L PAC). The arrangement of samples on the Jartest was described in Table 1.

Table 1. Sources of PAC applied to the study

\begin{tabular}{ccc} 
Beaker & Dosage (mg) & Notes \\
\hline $\mathrm{M}_{00}$ & 0 & Initial sample \\
$\mathrm{M}_{10}$ & 0 & Control sample \\
$\mathrm{M}_{11}$ & 150 & \\
$\mathrm{M}_{12}$ & 200 & \\
$\mathrm{M}_{13}$ & 250 & \\
$\mathrm{M}_{14}$ & 300 &
\end{tabular}

Experiment 2: determining the proper amount of Cassia fistula gum as the auxiliary coagulant (to treat the textile wastewater collected from two factories).

- Purpose: to compare the efficiency on improving the quality of wastewater of the auxiliary coagulants including the natural Cassia fistula gum and chemical-ly synthesized polymer.

- Procedure: the experimental setup was similar to the one in the experiment 1 . Herein, the used amount of PAC was the best one obtained from the previous experiment while the amount of polymer and biological Cassia fistula gum were fixed at $5.0 \mathrm{mg} / \mathrm{L}$. The recorded results would be the difference in treatment efficiency when combining PAC with polymer or Cassia fistula gum.

\section{Results and discussions}

\subsection{Analysis of input textile wastewater}

The results showed that the wastewater from both factories possessed an extremely high COD content and color intensity in comparison to both standard QCVN 13-MT:2015/ BTNMT - National technical regulation on the effluent of textile industry and standard QCVN 40:2011/ BTNMT National technical regulation on industrial wastewater. Therefore, it is essential to improve the quality of the wastewater before discharging to the receiving sources.

Table 2. Analytical results of input wastewater

\begin{tabular}{lccc} 
Parameter & $\begin{array}{c}\mathbf{1}^{\text {st fac- }} \\
\text { tory }\end{array}$ & $\begin{array}{c}\mathbf{2}^{\text {nd }} \\
\text { fac- } \\
\text { tory }\end{array}$ & $\begin{array}{c}\text { QCVN } \\
\mathbf{1 3 : 2 0 1 5} / \\
\text { BTNMT (col. } \\
\mathbf{A})\end{array}$ \\
\hline $\mathrm{pH}$ & 9.0 & 6.5 & $6-9$ \\
$\mathrm{COD}(\mathrm{mg} / \mathrm{L})$ & 800 & 910 & $75^{*}$ \\
Color (Pt- & 750 & 1035 & $50^{*}$ \\
Co) & & & $50^{* *}$ \\
SS (mg/L) & 162 & 512 &
\end{tabular}

*: applied for new factory

**: QCVN 40:2011/BTNMT (column A) - National technical regulation on industrial wastewater

\subsection{Determining the optimum amount of PAC}

As showed from Figures 1, 2 and 3, the treatment of $\mathrm{M}_{12}$ contained $200 \mathrm{mg} / \mathrm{L} \mathrm{PAC}$ at $\mathrm{pH}=7$ gave the best $\mathrm{SS}$, color intensity and COD values. Particularly, color intensity reduced to 110 Pt-Co with an efficiency of $85.3 \%$, COD content decreased to $337.3 \mathrm{mg} / \mathrm{L}$ with a removal efficiency of $57.8 \%$. Meanwhile, with a high treatment efficiency of $91.4 \%$, a low SS value of $14 \mathrm{mg} / \mathrm{L}$ was obtained. Then, PAC amount of $200 \mathrm{mg} / \mathrm{L}$ and $\mathrm{pH} 7$ were chosen for the other experiments to decide the best amount of needed substances for chemical polymer and biological gum.

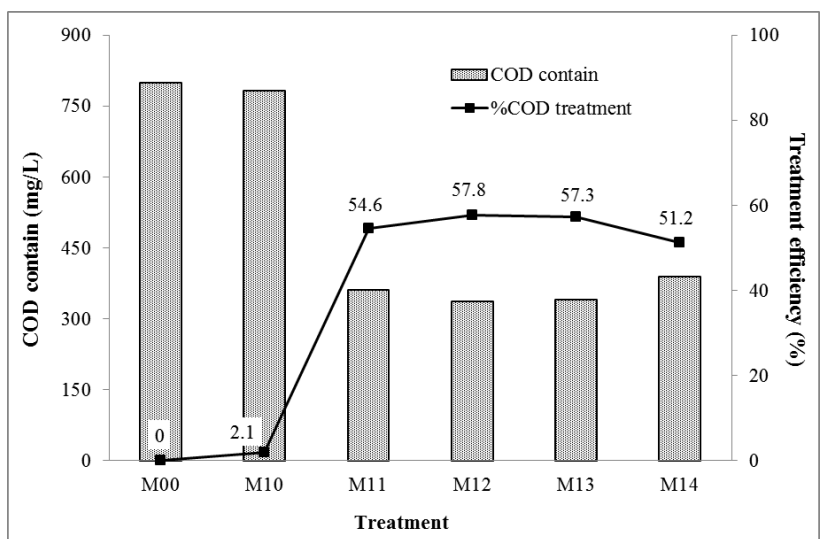

Figure 1. COD treatment efficiency vs PAC quantity

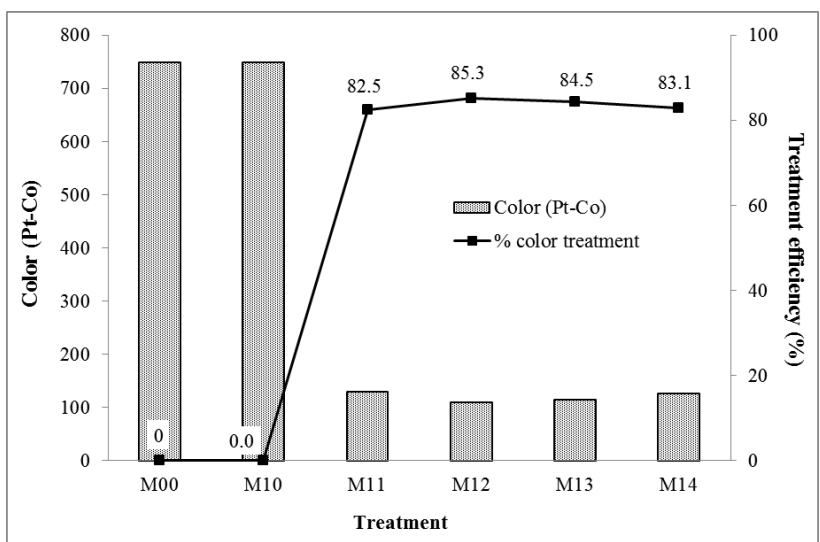

Figure 2. Color treatment efficiency vs PAC quantity

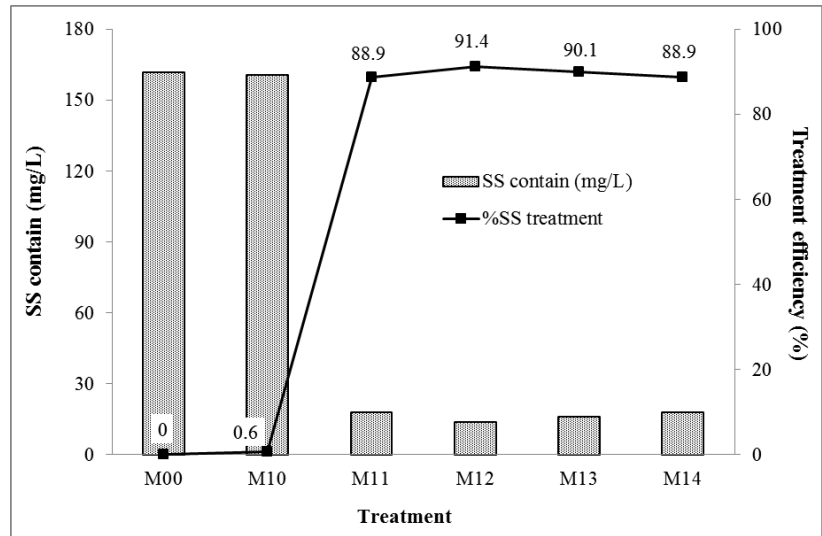

Figure 3. SS treatment efficiency vs PAC quantity 


\subsection{Evaluating the treatment efficiency}

\subsubsection{Treatment of wastewater from factory 1}

Figure 4 (left) showed that the coagulant PAC when combining with polymer as the auxiliary coagulant gave the highest efficiency in improving the quality of water. Indeed, this combination resulted in a color intensity of 95 Pt-Co with an efficiency of $87.3 \%$; COD content reached $317.3 \mathrm{mg} / \mathrm{L}$ with an efficiency of $60.3 \%$ and SS decreased to $11 \mathrm{mg} / \mathrm{L}$ with a removal efficiency of $93.2 \%$. In addition, when using the biological auxiliary coagulant, the obtained results of treatment were comparable with the chemical one as can be seen clearly from Figure 4. Particularly, a color intensity of $97 \mathrm{Pt}-\mathrm{Co}$ with an efficiency of $87.1 \%$; COD content of $322.4 \mathrm{mgO}_{2} / \mathrm{L}$ with a removal efficiency of $59.7 \%$ and an SS of $12 \mathrm{mg} / \mathrm{L}$ with an efficiency of $92.6 \%$ were achieved. In another word, textile wastewater can be treated by either chemical or biological substances.

\subsubsection{Treatment of wastewater from factory 2}

The analysis results clearly showed that the wastewater which was treated with PAC combined with polymer gave higher treatment efficiency in comparison to PAC combined with biological gum (Figure 4 - right). Particularly, the treatment efficiency based on COD, SS and color intensity were $57.52 \%, 76.56 \%, 57.87 \%$ respectively for the case of PAC polymer while the corresponding values in the case of biological gum were $52.33 \%, 75.00 \%$ and $52.27 \%$.
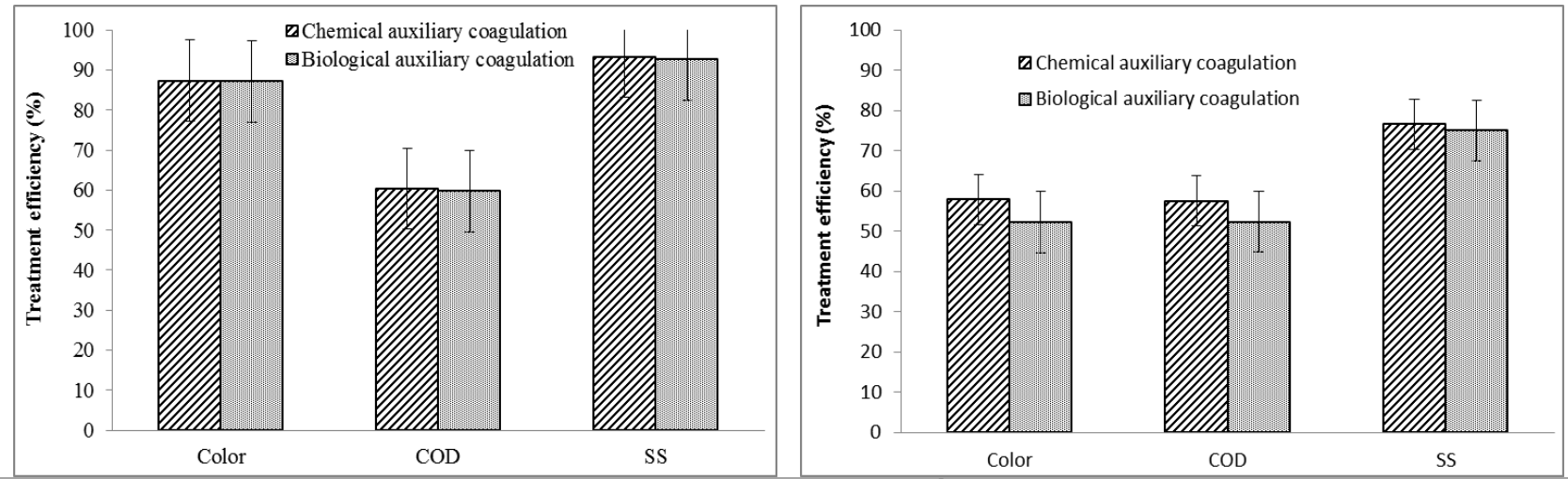

Figure 4. Wastewater treatment efficiency of $1^{\text {st }}$ factory (left) and $2^{\text {nd }}$ factory (right)

Table 2. Determining the best auxiliary coagulant

\begin{tabular}{|c|c|c|c|}
\hline Parameters $\quad$ Sample & $\mathbf{0}$ & 1 & 2 \\
\hline Wastewater (mL) & 500 & 500 & 500 \\
\hline $\mathrm{PAC}(\mathrm{mg} / \mathrm{L})$ & - & 200 & 200 \\
\hline Auxiliary coagulant (mg/L) & - & Polymer $(5 \mathrm{mg} / \mathrm{L})$ & Cassia fistula Gum (5 mg/L) \\
\hline $\mathrm{COD}(\mathrm{mg} / \mathrm{L})$ & $910 \pm 0.07$ & $386.61 \pm 0.01$ & $433.84 \pm 0.05$ \\
\hline $\mathrm{SS}(\mathrm{mg} / \mathrm{L})$ & $512 \pm 0.1$ & $120 \pm 0.04$ & $128 \pm 0.2$ \\
\hline Color (Pt-Co) & $1035 \pm 0.03$ & $436 \pm 0.1$ & $494 \pm 0.2$ \\
\hline
\end{tabular}

Bui Thi Vu (2012) reported that when using the coagulant with the PAC concentration of $500 \mathrm{mg} / \mathrm{L}$ at $\mathrm{pH}=7.5$, the COD treatment efficiency was $62.5 \%$. In another study, combination of the mixed Fe : Al (ratio of $1: 2$ ) showed the best treatment efficiency with a COD removal efficiency reached $89 \%$ when using $18 \mathrm{~mL}$ mixed alum for each litter of the examined wastewater (Ngo Kim Dinh et al., 2013). According to Dinh Tuan (2011), treating the textile wastewater by coagulation combined with electrolytic flotation with a corrosive anode $(\mathrm{Al}, \mathrm{Fe})$ resulted in a COD removal efficiency of $66.7 \%$.

Additionally, Smith et al. (1975) used $\mathrm{Al}_{2}\left(\mathrm{SO}_{4}\right)_{3}$ as coagulant in treating the wastewater from the stage before bleaching in textile dying and a high efficiency up to $95 \%$ based on SS was obtained when using the coagulant at concentration range of $70-100 \mathrm{mg} / \mathrm{L}$ (cited from Bui Thi Vu, 2012). Moreover, the study of Knocke et al. (1986; cited from Bui Thi $\mathrm{Vu}, 2012$ ) showed that color treatment of textile wastewater can be done using ferrous com-pounds such as $\mathrm{FeCl}_{3}$ and $\mathrm{FeSO}_{4}$. It was reported that using 300 $\mathrm{mg} / \mathrm{L} \mathrm{FeCl}_{3}$ gave a treatment efficiency of $95-99 \%$ while
$100 \%$ efficiency was achieved when using $500 \mathrm{mg} / \mathrm{L}$ $\mathrm{FeSO}_{4}$. According to another study on treating textile wastewater using potash alum and ferrous sulfate, when using the alum with concentration of $1.0 \mathrm{~g} / \mathrm{L}$, the efficiency in treating color was lower than $20 \%$. However, when combining the alum with flocculating agent, the color of the wastewater was almost completely removed (Duk Jong Joo et al., 2005).

In comparison with mentioned researches, in this study, the combination of PAC with either chemical polymer or biological Cassia fistula gum gave satisfactory results in handling textile wastewater by using physicochemical method. With these results, biological gum can be potentially used for wastewater treatment in the near future and gradually be able to substitute the chemical compounds.

\section{Conclusions}

In this study, we experimentally determined the optimum amounts of coagulant for improving the quality of textile wastewater using the Jartest apparatus. In particular, the 
concentration of coagulant PAC was $200 \mathrm{mg} / \mathrm{L}$ while the amount of auxiliary coagulants including polymer and Cassia fistula biological gum was $5.0 \mathrm{mg} / \mathrm{L}$.

In addition, when comparing the ability to apply chemical and biological polymers in treating the textile wastewater from two factories, it was found that these two types of auxiliary coagulants showed no remarkable differences in the treatment efficiency. Indeed, the efficiency based on COD measure was $59.70-52.33 \%$ for the biological gum and $60.30-57.52 \%$ for the chemical polymer while the efficiency evaluated by SS removal was quite high which was $92.6-75.0 \%$ in the case of the gum and was 93.2 $76.56 \%$ in the case of the polymer. Finally, the efficiency based on color intensity for the gum and the polymer reached $87.1-52.27 \%$ and $87.3-57.87 \%$, respectively. Consequently, it can be seen that the combination of biological compound in the improvement of wastewater quality is bringing new prospects to the wastewater treatment industry.

\section{References}

[1] Bhatnagar M., Parwani L., Sharma V., Ganguli J., Bhatnagar A. (2013). Hemostatic, antibacterial biopolymers from Acacia arabica (Lam.) Willd and Moringa oleifera (Lam.) as potential wound dressing materials. Indian Journal of Experimental Biology 51(10) 804-810.

[2] Bui Thi Vu (2012). Study of treating textile waste-water by coagulation combined with $\mathrm{H}_{2} \mathrm{O}_{2}$ oxidation using UV for the trial pilot model in the laboratory. Private Univeristy of Hai Phong (in Vietnamese).

[3] Dinh Tuan (2011). Study on handling textile wastewater using coagulation method - electrolytic flotation with aluminium, iron as corrosive anode. Master thesis, University of Danang (in Vietnamese).

[4] Duk Jong Joo, Won Sik Shin, Jeong Hak Choi, Sang June Choi, Myung Chul Kim, Myung Ho Han, Tae
Wook Han, Young Hun Kim (2005). Decolorization of reactive dyes using inorganic coagulants and synthetic polymer. Dyes and Pigments 73(3) 59-64.

[5] Huynh Long Toan (2014). Textbook on Practice of water and wastewater treatment engineering. Department of Environmental Engineering, Can Tho University (in Vietnamese).

[6] Le Xuan Hong (2006). Criteria of environmental impact assessment. Statistical Publishing House (in Vietnamese).

[7] Ngo Kim Dinh, Dao Minh Trung, Phan Thi Tuyet San (2013). Studying the ability to apply the mixture of alum and ferrous sulfate in water treatment by physiochemical method. Scientific Journal of Thu Dau Mot University 3(10) 46-52 (in Vietnamese).

[8] Nguyen Thi Lan Phuong (2008). Textbooks on water supply and drainage. Danang University of Technology (in Vietnamese).

[9] Pal A., Singh R. P. (2014). Nature of gum polysaccharide extracted from Moringa oleifera Lam. (Sainjna) plant. Advances in Applied Science Research 5(6) 1-3.

[10] Pham Ngoc Ho (2009). Environmental impact as-sessment. Vietnam National University of Hanoi Publishing House (in Vietnamese).

[11] Tran Hieu Nhue (2001). Water drainage and industrial wastewater treatment. Science and Technology Publishing House (in Vietnamese).

[12] Vietnam Environment Administration (2015). QCVN 13-MT:2015/BTNMT - National technical regulation on the effluent of textile industry.

[13] Vietnam Environment Administration (2011). QCVN 40:2011/BTNMT - National technical regulation on industrial wastewater. 